\title{
EFFECT OF MYCORRHIZAL FUNGI ON SESAME PRODUCTIVITY UNDER WATER STRESS IN LOW-INPUT AGRICULTURE SYSTEM
}

\author{
Esmaeil GHOLINEZHAD ${ }^{{ }^{*}}$, Reza DARVISHZADEH ${ }^{2}$ \\ ${ }^{I}$ Payame Noor University, Department of Agricultural Sciences, Tehran, IRAN \\ ${ }^{2}$ Urmia University, Department of Plant Breeding and Biotechnology, Urmia, IRAN \\ ${ }^{*}$ Corresponding author: Gholinezhad1358@yahoo.com
}

Received: 14.10 .2018

\begin{abstract}
Arbuscular mycorrhizal fungi are organisms that cause to enhance the resistance of having fungi to water stress. To survey the effects of various levels of water deficit and two kinds of mycorrhizal fungi on quantitative and qualitative traits of sesame (Sesamum indicum L.) cultivars, an experimental using factorialsplit plot design was carried out with three replications in the research field of Agricultural Research Center, West-Azerbaijan in 2015 and 2016 cropping seasons. The main plots (factor A and B) included different levels of irrigation; normal irrigation (irrigation after $70 \mathrm{~mm}$ evaporation of crop (ETc)), moderate water stress (irrigation after $90 \mathrm{~mm}$ ETc) and severe water stress (irrigation after $110 \mathrm{~mm} \mathrm{ETc}$ ) and factor B included three levels: two kinds of mycorrhizal fungi Funneliformis mosseae, Rhizophagus intraradices and noninoculated (control). Sub plots (factor C) consisted of eight commercial cultivars of sesame named "single branch Naz", "several branches Naz", "Dashtestan 5", "Dashtestan 2", "Darab 2", "Darab 14", "Halil" and "Pal". Mean comparison of 2-yr showed that with enhancing severity of water deficit, all studied traits decreased. Severe water stress reduced seed yield, oil yield, protein yield and biological yield about 64, 65, 62 and 40 percent, respectively. Using two kinds of mycorrhizal fungi $F$. mosseae, $R$. intraradices compared to non-inoculated (control) traits quantitative and qualitative traits increased. Also in three different irrigation conditions, "Darab 2" and "Darab 14" were superior commercial cultivars. To improve quantitative and qualitative traits of sesame, use of mycorrhizal fungi, especially $F$. mosseae was found to be recommendable.
\end{abstract}

Keywords: Commercial cultivars, mycorrhiza, oily crops, seed yield, water stress

\section{INTRODUCTION}

The area under cultivation of sesame crop is about 7897048 hectares in the world and its production is about 4036289 tons with an average yield of $511 \mathrm{~kg}$ per hectare. In Iran, the cultivated area of sesame is about 40,000 hectares and its production is about 28,000 tons with an average yield of $700 \mathrm{~kg}$ per hectare (FAO, 2016). Pretransplant inoculation with mycorhizal fungi enhanced tomato root colonization at flowering and harvest compared to the non-inoculated plants (31.8 vs $23.6 \%)$ (Mugendi Njeru et al., 2017). Sesame (Sesamum indicum L.) is one of the most important oil crops in temperate and tropical regions and is grown worldwide over (Phumichai et al., 2017).

Many reports have shown that water stresses have adverse effects on plant growth and productivity (Bahrami et al., 2012). Long and dense capsule characteristics in sesame are associated with high seed yield (Yol et al., 2017). Yol et al. (2013) indicated that importance for further improvement of high antioxidant capacity in sesame. Long irrigation intervals reduce sesame growth and seed yield due to the effect on photosynthetic apparatus (Mensah et al., 2006). At maturity and in most commercial cultivars, capsules dehisce along their sutures and shatter their seeds on the ground (Diouf et al., 2010). Heidari et al. (2011) showed that the highest sesame seed yield is obtained under favorable irrigation conditions. Other researchers also stated that different irrigation treatments had a significant effect on biomass, seed yield and oil yield of sesame (Rezvani Moghaddam et al., 2014). In their experiment, the highest number of seed per capsule and the highest number of capsule on plant were observed in "Darab 14" and "Sirjan" ecotypes. Increasing irrigation intervals reduced growth and yield of sesame seeds as well as oil and protein content (Mensah et al., 2006). The results of a study (Mensah et al., 2006) showed that with extending irrigation intervals, seed yield of sesame decreased from $6.09 \mathrm{~g}$ per plant to $5.9 \mathrm{~g}$ per plant. RWC can indicate the equilibrium across attracted moisture by plant and used via transpiration (Ganji Arjenaki et al., 2012). Mycorrhiza is the most important fungi that found mostly on not damaged soils. It is estimated that about $70 \%$ of the mass of the microbial community of the soil contain the mycelium of this fungi (Rejali et al., 2007). Cho et al. (2006) found that the 
symbiosis of sorghum with mycorrhizal fungi under water stress conditions increased its tolerance to stress. Jamshidi et al. (2009) showed that G. mosseae had more symbiosis power compared to $G$. hoei fungus in sunflower plant. Various studies have shown that the symbiosis of mycorrhizal fungi with plant roots improves the growth and development of host plants in sustainable farming systems by improving the absorption of nutrients such as phosphorus, nitrogen and some elements of micro nutrition, increasing water absorption and increasing resistance to pathogenic agents (Sainz et al., 1998). Haghighatnia et al. (2012) stated that mycorrhizal colonization, especially by $G$. mosseae, improves resistance to water stress and compensates for some of the reduction in yield. There is still limited information on the symbiosis of sesame with these fungi under water stress. So this experiment was conducted to study the effects of several levels of water deficit and the symbiosis of two different species of mycorrhizal fungi on yield and seed yield components, oil and protein percentages, and oil and protein yields on different commercial cultivars of sesame in Urmia, Iran.

\section{MATERIALS AND METHODS}

The study was done in two years successive-years 2015 and 2016 in the research farm of Shahid Beheshti Agricultural high school with $37^{\circ} 32^{\prime} \mathrm{N}$ and $45^{\circ} 5^{\prime} \mathrm{E}$ and 1352 meters above sea level (Urmia, Iran).

\section{Experimental design and treatments}

This research was carried out as factorial-split plot design with 3 replications. The main plots (factor A and B) included different levels of irrigation; normal irrigation (irrigation after $70 \mathrm{~mm}$ evaporation of crop (ETc)), moderate water stress (irrigation after $90 \mathrm{~mm} \mathrm{ETc}$ ) and severe water stress (irrigation after $110 \mathrm{~mm} \mathrm{ETc}$ ) and factor B included three levels: Glomus mosseae (Nicol. \& Gerd, the new name is Funneliformis mosseae) BEG 12, Glomus intraradices (Schenck \& Smith, the new name is Rhizophagus irregularis) and non-inoculated (control). Sub plots (factor C) consisted of eight commercial cultivars of sesame including "single branch Naz", "several branches Naz", "Dashtestan 5", "Dashtestan 2", "Darab 2", "Darab 14", "Halil" and "Pal". There were materials such as sterile sand, mycorrhizal hyphae, spores (20 spores per gram), and colonized root fragments in mycorrhizal inoculums. Into the hole below each seed about 10 grams of the appropriate inoculum was put and next concealed with the soil. For nonmycorrhizal control plants, sesame plants were sown with no inoculation. The seeds were cultivated in 2015 on May 20 and in 2016 on May 13, with plant spacing of 50 by $15 \mathrm{~cm}$ containing 133333 plants ha $^{-1}$. Each plot had 4 sowing lines of 4 meters in length. Cultivation and irrigation was done by furrowing and leakage method, respectively. At the time of planting, three seeds were placed in each clump and then they were thinned in 2-4 leaf stage. All treatments were irrigated to 2-4 leaf, similarly. After this stage, several levels of water deficit were applied. The distance between sub-plots was considered one non-planted line and the between the two main plots considered two meters. Therefore, the area of each sub plot and main plot was 10 and 96 square meters, respectively. The total area of the experiment, taking into account the intervals between experimental units and irrigation canals, was about 3000 square meters.

\section{Meteorological properties of the region}

The experiment was set in a location, $25 \mathrm{~km}$ far from Urmia, and the region is considered to be arid and semiarid in climatic conditions. According to the long-term meteorological data, the average annual rainfall is 390 $\mathrm{mm}$, the average temperature is $11.3^{\circ} \mathrm{C}$, and the relative humidity is $75 \%$.

\section{Chemical and physical properties of soil in the test site}

The soil was test loam-clay loam, pH 8 and Ec was about $1.5 \mathrm{ds} / \mathrm{m}$, which was not a problem for sesame cultivation.

\section{Growing Plants}

The planting of the first year was carried out on May 10, 2015 and the second year on May 3, 2016 by hand and in a manner of wet planting (i.e. at first irrigation was done and then after 3 days seeds planted). The seeds were disinfected with benomyl 2 part per thousand before planting. The first irrigation was done about 10 days after planting. Weeding of weeds was done manually in two stages, 20 and 40 days after planting. There was no specific disease and pest in the field. To remove the edge effect, the side rows and half of meter from the beginning and the end of each row were removed.

Eight commercial cultivars of sesame i.e., 1- "single branch Naz", 2- "several branch Naz", 3- "Dashtestan 5", 4- "Dashtestan 2", 5- "Darab 2", 6- "Darab 14", 7"Halil" and 8- "Pal" were used.

\section{Method of application of different irrigation treatments}

Bulk density, field capacity and permanent wilting point were calculated $1.37,25$ and 12 , respectively.

$\mathrm{RAW}=\frac{\mathrm{FC}-\mathrm{PWP}}{100} \times \rho \times \mathrm{D} \times \mathrm{MAD}$

Where RAW is the readility available water $(\mathrm{mm}), \mathrm{FC}$ is field capacity (\%), PWP is the permanent wilting point (\%), $\rho$ is the bulk density, D is the root zone depth (mm) and MAD is the coefficient of water easy to use. In loam clay loam soil, the soil capacity of 25 and the wilting point is constant 12 . The bulk density is 1.37 . Root development depth in sesame was $600 \mathrm{~mm}$. The coefficient of water easy to use is F or MAD or $\theta$.

$R A W=\frac{25-12}{100} \times 1.37 \times 600 \times 0.65$

MAD = coefficient of water easy to use is the same water that can be used between field capacity and permanent wilting point. The coefficient was 0.65 for optimal irrigation and 0.8 for moderate water stress and 0.95 for severe water stress. Under optimum irrigation, 
moderate water stress and severe water stress conditions, RAW were 70,85 and $100 \mathrm{~mm}$, respectively, which was considered to be the equivalent of $\mathrm{ET}_{\mathrm{C}}$ or evapotranspiration.

$$
E T o=E T p \times K p \quad E T c=E T o \times K c \quad(\text { Eq. 3) }
$$

Where ETo is the potential evapotranspiration, ETp is the pan evapotranspiration, ETc is the crop evapotranspiration, $\mathrm{Kp}$ is the pan coefficient and $\mathrm{Kc}$ is the crop coefficient of sesame.

Irrigation water was evaluated using Type III flumes (Washington State College). The mouth width and head of III flumes were 304.8 and $30 \mathrm{~mm}$, respectively (Chamberlain, 1952).

\section{Parameters measured}

\section{Yield and Yield Components}

In order to determine the moisture content of different plant organs and calculate the total dry matter and seed yield, randomized samples were collected from different parts of the plant and seeds of each plot and dried at $72^{\circ} \mathrm{C}$ for 48 hours and according to the initial weight of organs and seeds, total dry matter and seed yield were corrected based on their dry weight. The yield components including the number of seeds per capsule and 1000-seed weight were calculated. The Harvest index (HI) was calculated using Equation 4 (Fagria, 1995):

$$
H I=\frac{G y}{B y} \times 100 \quad(\text { Eq. } 4)
$$

Where $\mathrm{HI}$ is the harvest index, Gy is the seed yield and By is the biological yield. For measuring 1000-seed weight 7 replicates of 200 samples of each treatment was selected, then averaged and multiplied by 5. For measuring number of seed per capsule 5 capsules of each treatment was selected, then averaged. For determining number of capsule per plant, 5 plants of each treatment was selected, and then averaged.

\section{Percentage of colonization}

The percentage of colonization of sesame roots by mycorrhizal fungi was measured on 15 plants per experimental unit at stage of plant maturity. The percentage of root colonization by AM fungi was microscopically assessed using the gridline intersection method (Xue-Guang and Ming, 2012).

\section{Oil and protein}

The oil percentage was measured by a Soxhlet apparatus (A.O.A.C., 1990) and protein percentage with the Kjehldal model of the V40 model. The oil yield was calculated from multiplying oil percentage in seed yield and protein yield was measured from multiplying protein percentage in seed yield.

\section{Relative water content}

For determining RWC, leaf fresh weight samples were measured, and were placed into distilled water then after $24 \mathrm{~h}$ were weighed. Eventually were located at $70^{\circ} \mathrm{C}$ for
$48 \mathrm{~h}$ and were weighed again. RWC was measured based on Dhopte and Manuel (2002):

$\mathrm{RWC}=(\mathrm{FW}-\mathrm{DW} / \mathrm{TW}-\mathrm{DW}) \times 100$

Where, FW is fresh weight, DW is dry weight and TW is turger weight of leaf samples.

\section{Statistical analysis}

To normalize some traits such as number of seed per square meter, number of seed per capsule, number of capsule per plant and number of branches, square root conversion (SQRT) technique and for root colonization percentage, arcsine-sqare root transformation were used. Combined analysis of factorial split plot experiments based on randomized complete block design was performed using SAS software. The homogeneity of error variances was test using Bartlett test. To reduce Type 1 error, Bonferroni correction was done for variance analysis and correlation coefficients. Comparison of the means was done by SNK test at 5\% level in MSTATC software.

\section{RESULTS}

Based on results of mean comparison, the inoculation with mycorrhizal fungi of $F$. mosseae and $R$. intraradices compared to non-inoculated plants increased the harvest index by (10 and 6\%), 1000-seed weight (16 and 10\%) and the number of capsule per plant (40 and 26\%), respectively (Table 1). Based on results of this study, there was a significant difference between the application and non-application of mycorrhiza fungi on biological yield, although there was no significant difference between two species of fungi in term of biological yield (Table 1). Inoculation with mycorrhizal fungi of $F$. mosseae and $R$. intraradices compared to noninoculated plants led to increase biological yield about 40 and 27 percent, respectively (Table 1). Applying with mycorrhizal fungus of $F$. mosseae and $R$. intraradices compared to uninoculated plants led to increase relative water content about 38 and 29 percent, respectively (Table 1). Severe and moderate water stress, in comparison to optimum irrigation, reduced the oil percentage about (6 and 4\%) and the biological yield (52 and 43\%), respectively (Table 2). Mean comparison of irrigation and cultivars interactions showed that the highest number of capsule per plant was obtained from "Darab 2" (116.63) in optimum irrigation condition and the lowest number of capsule per plant belonged to "single branch Naz" (10.34) under severe water stress conditions (Table 3 ). The maximum oil percentage was obtained from "Dashtestan 2" (44.15\%) in normal irrigation and the minimum one in "Dashtestan 2 " $(40.98 \%)$ under severe water stress (Table 3). Mean comparisons of irrigation $\times$ cultivar interactions data showed that the highest biological yield obtained from "Darab 2" (538.55 $\left.\mathrm{g} \mathrm{m}^{-2}\right)$ under optimum irrigation conditions and the lowest one on "single branch Naz" (43.11 $\mathrm{g} \mathrm{m}^{-2}$ ) and "Halil" (57.42 $\mathrm{g} \mathrm{m}^{-2}$ ) under severe water stress conditions (Table 3). Mean comparisons of irrigation $\times$ cultivar interactions showed that the highest 
relative water content was obtained from "Darab 2" lowest one obtained from "Pal" (23.73\%) under severe $(61.29 \%)$ under favorable irrigation conditions and the water stress conditions (Table 3).

Table 1. Comparison mean of simple effects of mycorrhizal on studied traits in two years (maximum and minimum of values presented).

\begin{tabular}{llllll}
\hline Mycorrhizal & $\begin{array}{l}\text { Harvest } \\
\text { index } \\
(\%)\end{array}$ & $\begin{array}{l}\mathbf{1 0 0 0 - s e e d} \\
\text { weight }(\mathbf{g})\end{array}$ & $\begin{array}{l}\text { Number of capsule } \\
\text { per plant }\end{array}$ & $\begin{array}{l}\text { Biological } \\
\text { yield } \\
\left(\mathbf{g ~ m}^{-2}\right)\end{array}$ & $\begin{array}{l}\text { Relative water } \\
\text { content }(\%)\end{array}$ \\
\hline $\begin{array}{l}\text { Funneliformis } \\
\text { mosseae }\end{array}$ & $25.32 \mathrm{a}$ & $2.14 \mathrm{a}$ & $55.84 \mathrm{a}$ & $239.48 \mathrm{a}$ & $50.80 \mathrm{a}$ \\
$\begin{array}{l}\text { Non- inoculated } \\
\text { (control) }\end{array}$ & $22.92 \mathrm{a}$ & $1.80 \mathrm{c}$ & $34.06 \mathrm{~b}$ & $146.37 \mathrm{~b}$ & $31.51 \mathrm{c}$ \\
\hline
\end{tabular}

Table 2. Comparison mean of irrigation and mycorrhizal interaction on studied traits in two years (maximum and minimum of values presented).

\begin{tabular}{|c|c|c|c|}
\hline \multicolumn{2}{|c|}{ Treatment (Irrigation $\times$ Mycorrhizal) } & Number of seed per capsule & Oil percentage $(\%)$ \\
\hline Optimum irrigation $\times$ & $\begin{array}{l}\text { Funneliformis mosseae } \\
\text { Rhizophagus intraradices }\end{array}$ & $\begin{array}{l}72.95 \mathrm{a} \\
-\end{array}$ & $44.49 \mathrm{a}$ \\
\hline Severe water stress $x$ & Non-inoculated (control) & $28.95 \mathrm{~h}$ & $40.55 \mathrm{i}$ \\
\hline
\end{tabular}

Mean in each column followed by the same letter(s) are not significant different at $1 \%$ probability level according to SNK Test.

Table 3. Comparison mean of irrigation and cultivar interaction on studied traits in two years (maximum and minimum of values presented).

\begin{tabular}{|c|c|c|c|c|c|c|c|c|}
\hline $\begin{array}{l}\text { Treatment } \\
(\mathrm{I} \times \mathbf{C})\end{array}$ & & $\begin{array}{l}\text { Harvest } \\
\text { index } \\
(\%)\end{array}$ & $\begin{array}{l}\text { Number } \\
\text { of seed } \\
\text { per } \\
\text { capsule } \\
\end{array}$ & $\begin{array}{l}1000- \\
\text { seed } \\
\text { weight } \\
\text { (g) }\end{array}$ & $\begin{array}{l}\text { Number } \\
\text { of capsule } \\
\text { per plant }\end{array}$ & $\begin{array}{l}\text { Oil } \\
\text { percentage } \\
(\%)\end{array}$ & $\begin{array}{l}\text { Biological } \\
\text { yield } \\
\left(\mathrm{g} \mathrm{m}^{-2}\right) \\
\end{array}$ & $\begin{array}{l}\text { Relative } \\
\text { water } \\
\text { content } \\
(\%) \\
\end{array}$ \\
\hline \multirow{2}{*}{$\begin{array}{l}\text { Optimum } \\
\text { irrigation } \\
\times\end{array}$} & $\begin{array}{l}\text { Dashtestan } \\
2\end{array}$ & - & - & - & - & $44.15 \mathrm{a}$ & - & - \\
\hline & Darab 2 & $31.75 \mathrm{a}$ & $78.22 \mathrm{a}$ & $2.47 \mathrm{a}$ & $116.63 \mathrm{a}$ & - & $538.55 \mathrm{a}$ & $61.29 \mathrm{a}$ \\
\hline \multirow{3}{*}{$\begin{array}{l}\text { Severe } \\
\text { water } \\
\text { stress } \times\end{array}$} & $\begin{array}{l}\text { Single } \\
\text { branch Naz }\end{array}$ & $18.19 \mathrm{i}$ & $25.11 \mathrm{x}$ & $1.43 \mathrm{w}$ & $10.34 \mathrm{~m}$ & - & $43.11 \mathrm{k}$ & - \\
\hline & $\begin{array}{l}\text { Dashtestan } \\
2\end{array}$ & - & - & - & - & $40.98 \mathrm{w}$ & - & - \\
\hline & Pal & - & - & - & - & - & - & $23.73 \mathrm{i}$ \\
\hline
\end{tabular}

With increasing water stress, relative water content decreased significantly, so that severe and moderate water stress compared to optimum irrigation reduced the relative water content about 24 and 22 percent, respectively (Table 3 ). An examination of the average number of seeds per capsule indicates that severe water stress in comparison with optimum irrigation conditions reduced the number of seeds per capsule in "Darab 2" and "single branch Naz" by 38 and 50 percent, respectively (Table 3 ). Mean comparions of two-years of the traits indicated that with enhancing the intensity of water deficit, the seed yield decreased significantly, so that severe and moderate water stress in comparison with optimum iririgation, reduced seed yield by 64 and 20 percent, respectively (Table 4). Under favorable irrigation conditions, inoculation with mycorrhizal fungi of $F$. mosseae and $R$. intraradices compared with the non-inoculated plants improved the seed yield by $66 \%$ and $34 \%$, respectively. Under moderate water stress conditions, inoculation with mycorrhizal fungi of $F$. mosseae and $R$. intraradices compared with the non-inoculated plants increased seed yield about $60 \%$ and $35 \%$, respectively. In severe water stress conditions, inoculation with mycorrhizal fungi of $F$. mosseae and $R$. intraradices compared with the non-inoculated plants increased the seed yield by $115 \%$ and $60 \%$. Among the studied cultivars, the highest seed yield was observed in "Darab 2" (226.10 $\mathrm{g} \mathrm{m}^{-2}$ ) and "Darab 14" (159.30 $\mathrm{g} \mathrm{m}^{-2}$ ) under optimum irrigation conditions and inoculation with mycorrhizal fungus of $F$. mosseae species and the lowest one observed in "single branch Naz" (3.71 $\mathrm{g} \mathrm{m}^{-2}$ ) and "Halil" (5.30 $\left.\mathrm{g} \mathrm{m}^{-2}\right)$ were observed under severe water stress conditions without inoculation with mycorrhizal fungi (Table 4). With increasing water stress, the percentage of root colonization decreased significantly, so that severe and moderate water stress strongly reduced the percentage of root colonization by 47 and 20 percent, respectively, compared to optimum irrigation conditions (Table 4). 
Table 4. Comparison mean of irrigation, mycorrhizal and cultivar interaction on studied traits in two years (maximum and minimum of values presented).

\begin{tabular}{|c|c|c|c|c|c|c|c|}
\hline $\begin{array}{l}\text { Treatment } \\
(\mathbf{I} \times \mathbf{M} \times \mathbf{C})\end{array}$ & & & $\begin{array}{l}\text { Seed } \\
\text { yield (g } \\
\left.\mathrm{m}^{-2}\right)\end{array}$ & $\begin{array}{l}\text { Root } \\
\text { colonization } \\
(\%)\end{array}$ & $\begin{array}{l}\text { Oil } \\
\text { yield } \\
\left(\mathrm{g} \mathrm{m}^{-2}\right)\end{array}$ & $\begin{array}{l}\text { Protein } \\
\text { yield } \\
\left(\mathrm{g} \mathrm{m}^{-2}\right)\end{array}$ & $\begin{array}{l}\text { Protein } \\
\text { percentage } \\
(\%)\end{array}$ \\
\hline \multirow[b]{2}{*}{$\begin{array}{l}\text { Optimum } \\
\text { irrigation } \times\end{array}$} & $\begin{array}{l}\text { Funneliformis } \\
\text { mosseae }\end{array}$ & & $226.10 \mathrm{a}$ & $71.08 \mathrm{a}$ & $\begin{array}{l}100.50 \\
\mathrm{a}\end{array}$ & $56.00 \mathrm{a}$ & - \\
\hline & $\begin{array}{l}\text { Non-inoculated } \\
\text { (control) }\end{array}$ & $\begin{array}{l}\text { Single } \\
\text { branch } \\
\text { Naz } \\
\end{array}$ & - & - & - & - & $21.62 \mathrm{z}$ \\
\hline \multirow{2}{*}{$\begin{array}{l}\text { Severe water } \\
\text { stress } \times\end{array}$} & $\begin{array}{l}\text { Non-inoculated } \\
\text { (control) }\end{array}$ & $\begin{array}{l}\text { Single } \\
\text { branch } \\
\text { Naz }\end{array}$ & $3.71 \mathrm{z}$ & $6.08 \mathrm{z}$ & $1.52 \mathrm{z}$ & $0.88 \mathrm{z}$ & - \\
\hline & $\begin{array}{l}\text { Rhizophagus } \\
\text { intraradices }\end{array}$ & Halil & - & - & - & - & $25.34 \mathrm{a}$ \\
\hline
\end{tabular}

Mean in each column followed by the same letter(s) are not significant different at $1 \%$ probability level according to SNK Test.

In optimum irrigation conditions, inoculation with mycorrhizal fungi of $F$. mosseae and $R$. intraradices compared to non-use of mycorrhizal fungi improved the percentage of root colonization by 64 and 60 percent, respectively. Under moderate water stress conditions, an increase in the percentage of root colonization was about 70 and 64 percent, respectively, in inoculation with mycorrhizal fungi of $F$. mosseae and $R$. intraradices compared to non-use of mycorrhizal fungi. In severe water stress conditions, inoculation with mycorrhizal fungi of $F$. mosseae and $R$. intraradices compared to non-use of mycorrhizal fungi increased the percentage of root colonization by 74 and 70 percent, respectively. Among the cultivars studied, the highest percentage of root colonization was seen in "Darab 2" $(71.08 \%)$ and "Darab $14 "(67.08 \%)$ cultivars in optimum irrigation and inoculation with mycorrhizal fungus of F. mosseae species and the lowest one was obseved in "single branch Naz" $(6.08 \%)$ and "several branches Naz" (6.75\%) under severe water stress and without inoculation with mycorrhizal fungus (Table 4). Based on our research, with increasing water stress, oil yield decreased significantly, i.e. severe and moderate water stress compared to optimum irrigation reduced oil yield by $65 \%$ and 23 percent, respectively (Table 4). In optimum irrigation conditions, inoculation of $F$. mosseae and $R$. intraradices with mycorrhizal fungi compared to non-use of mycorrhiza fungi improved oil yield by 42 and 28 percent, respectively. Under moderate water stress conditions, increasing of oil yield, under conditions of inoculation with mycorrhizal fungus of $F$. mosseae and $R$. intraradices compared to non-use of mycorrhiza fungi, was about 39 and 28 percent, respectively. In severe water stress conditions, the inoculation of $F$. mosseae and $R$. intraradices compared to non-use of mycorrhiza fungi increased the oil yield by 55 and 40 percent, respectively. Among the cultivars studied, the highest oil yield was obtained in "Darab 2" (100.50 g $\mathrm{m}^{-2}$ ) under optimum irrigation conditions and inoculated with mycorrhizal fungus $\mathrm{F}$. mosseae and the lowest oil yield in "single branch Naz" (1.52 $\left.\mathrm{g} \mathrm{m}^{-2}\right)$ and "Halil" (2.15 $\mathrm{g} \mathrm{m}^{-2}$ ) were observed under severe water stress conditions without inoculation with mycorrhizal fungus (Table 4). In all different levels of irrigation, inoculation with mycorrhizal fungi $F$. mosseae and $R$. intraradices compared to non-use of mycorrhiza fungi increased the oil percentage. Severe and moderate water stress compared to optimum irrigation reduced protein yield about 62 and 20 percent, respectively (Table 4). Reduction of protein yield is due to reducing seed yield under water deficit conditions. With enhancing water deficit, the protein percentage increased remarkably, so that severe and moderate water stress compared to optimum irrigation increased significantly protein percentage about 5 and 3 percent, respectively (Table 4). In all different levels of irrigation conditions, application of mycorrhizal fungi of $F$. mosseae and $R$. intraradices compared to uninoculated plants improved protein percentage. Among the studied cultivars, the highest protein percentage was observed in "Pal" cultivar $(25.34 \%)$ under severe water stress conditions and inoculation with mycorrhizal fungus $(F$. mosseae) and the lowest one observed in "single branch Naz" (21.62\%) and "Halil" (21.69\%) under favorable irrigation conditions without inoculation with mycorrhizal fungi (Table 4). The amount of seed yield in 2016 was more than 2015 (Table 5). The rate of harvest index in 2yr was different (Table 5). Table 5 shows that the most number of seeds per capsule was produced in 2016 (Table 5). 1000-seed weight was in higher in 2016 than in 2015 (Table 5). The number of capsule per plant in 2016 would be greater than 2015. The maximum percentage of root colonization was observed in 2016 (Table 5). The amount of protein yield in 2015 and 2016 was different (Table 5). The highest protein percentage produced in 2015 (Table 5 ). The amount of biological yield in the second year was more than in the first year (Table 5). The amount of RWC was in geater in 2016 than in 2015 (Table 5). 
Table 5. Comparison means between 2 years for sesame traits

\begin{tabular}{|c|c|c|c|c|c|c|}
\hline Year & $\begin{array}{l}\text { Root colonization } \\
(\%)\end{array}$ & $\begin{array}{l}\text { Number of } \\
\text { capsule per plant }\end{array}$ & $\begin{array}{l}\text { 1000-seed } \\
\text { weight } \\
\text { (g) }\end{array}$ & $\begin{array}{l}\text { Number of seed } \\
\text { per capsule }\end{array}$ & $\begin{array}{l}\text { Harvest } \\
\text { index } \\
(\%)\end{array}$ & $\begin{array}{l}\text { Seed yield } \\
\left(\mathrm{g} \mathrm{m}^{-2}\right)\end{array}$ \\
\hline 2015 & $25.52 \mathrm{~b}$ & $35.00 \mathrm{~b}$ & $1.94 \mathrm{~b}$ & $49.26 \mathrm{~b}$ & $21.49 \mathrm{~b}$ & $43.70 \mathrm{~b}$ \\
\hline 2016 & $35.98 \mathrm{a}$ & $55.44 \mathrm{a}$ & $2.02 \mathrm{a}$ & $53.25 \mathrm{a}$ & $26.86 \mathrm{a}$ & $65.62 \mathrm{a}$ \\
\hline Year & $\begin{array}{l}\text { Relative water } \\
\text { content (\%) }\end{array}$ & $\begin{array}{l}\text { Biological yield (g } \\
\mathbf{m}^{-2} \text { ) }\end{array}$ & $\begin{array}{l}\text { Protein } \\
\text { percentage (\%) }\end{array}$ & $\begin{array}{l}\text { Protein yield } \\
\left(\mathrm{g} \mathrm{m}^{-2}\right)\end{array}$ & $\begin{array}{l}\text { Oil } \\
\text { percentage } \\
(\%)\end{array}$ & $\begin{array}{l}\text { Oil yield } \\
\left(\mathrm{g} \mathrm{m}^{-2}\right)\end{array}$ \\
\hline 2015 & $5 b$ & $4 \mathrm{~b}$ & $24.35 \mathrm{a}$ & 10. & $42.13 \mathrm{~b}$ & 18.5 \\
\hline 2016 & $50.61 \mathrm{a}$ & $222.70 \mathrm{a}$ & $23.64 \mathrm{~b}$ & $28.39 \mathrm{a}$ & $42.80 \mathrm{a}$ & $68.66 \mathrm{a}$ \\
\hline
\end{tabular}

Means followed by the same letter in each column are not significantly different.

\section{DISCUSSION}

Reduction of grain yield under water deficit can be due to the closure of stomata, increasing enzymes of protein degradation and chlorophyll which reduces the rate and amount of photosynthesis, the amount of photosynthetic materials, and finally the seed yield (Gholinezhad et al., 2009 and 2010). The cause of increasing seed yield due to use of fungi can be related to the improvement of seed yield components such as the number of capsule per plant, the number of seeds per capsule and the 1000-seed weight. In other words, the use of mycorrhizal fungi in comparison with the non-consumption of mycorrhiza fungi caused an increase of seed yield components and finally increased seed yield. The reason for this may be related to the effect of mycorrhiza on leaf retention on the plant, maintaining and increasing the leaf size, and improving the photosynthesis rate due to more chlorophyll (Habibzadeh et al., 2012). The effect of mycorrhiza in improving seed yield under severe water stress was more effective than optimum irrigation conditions. The results of studies show the complement effect of mycorrhizal fungi during water stress via increasing leaf water potential, increasing the rate of carbon dioxide consumption and increasing transpiration also, increasing the amount of water absorption per unit time and per root length of the host plant (Ladjal et al., 2005). Differences between cultivars in the harvest index may be due to a genetic difference between them in terms of the capacity to allocate photosynthetic produce to the reproductive sector and the seed. Low reduction of biomass yield compared to seed yield caused a decrease in harvest index in moisture stress conditions. Reduction of harvest index due to severe water stress during seed filling in other studies has also been reported. The highest harvest index is related to normal irrigation levels (Davoodi Fard et al., 2011). Our findings indicated that in conditions of water restriction, inoculation with mycorrhizal fungus compensates partially undesirable effects of water deficit and it prevents a major decline in the number of seeds per capsule. Raei et al. (2015) in safflower plants reported that the application of mycorrhiza increased the number of seeds per head. We also observed an increase in 1000seed weight when commercial cultivars of sesame were inoculated with $F$. mosseae and $R$. intraradices. Jamshidi et al. (2009) stated that the application of mycorrhiza increased 1000-seed weight and thus seed yield of sunflower increased under water stress and normal conditions. With increasing water stress, 1000-seed weight decreased significantly. It seems that reducing 1000 -seed weight under water stress is due to the shortening of the seed filling period and early aging. By extending the intensity of water deficit, capsules per plant decreased significantly. Mehrabi and Ehsanzadeh (2011) in studying physiological characteristics and yield of four sesame cultivars under different soil moisture regimes showed that under water stress, capsules per plant lessened by $42 \%$. Sogut (2009) showed that differences in seed yield and capsule number observed across genotypes were associated with the genetic differences among genotypes. 1000-seed weight also varied among genotypes. The highest value obtained for $\mathrm{Y}-\mathrm{C} 12, \mathrm{Y}-13$ and Y-A30 genotypes (4.23, 4.04 and $4.03 \mathrm{~g}$, respectively). The other genotypes had similar seed weight ranged from 3.44- $3.94 \mathrm{~g}$ (Sogut, 2009). In its study, the use of mycorrhiza fungi in general increased capsules per plant and the highest capsules per plant was observed in $F$. mosseae fungus inoculation. Commercial cultivars of sesame had preferable root colonization by $F$. mosseae than by $R$. intraradices. While a sloping trend of colonization happened companian with intensity of water stress (from irrigation after 70 to $110 \mathrm{~mm}$ of evaporation). The lowest of mycorrhizal colonization generated in the severe water stress treatment. In all levels of irrigation, application of $F$. mosseae and $R$. intraradices enhanced percentage of root colonization. Aslani et al. (2011) exported that with enhancing water stress, dry weight of root, dry and wet matter yield, phosphorous concentration and root colonization percentage decreased. In our study, with increasing water stress, oil percentage and oil yield decreased. Reduction of oil yield is due to decreasing seed yield under water deficit conditions. In the research works on sesame (Rezvani Moghaddam et al., 2014) were reported that the highest oil yield was observed at irrigation intervals of one week and the lowest one observed at irrigated intervals of 4 weeks. The high oil yield in these cultivars was due to higher seed yield as there was positively significant correlation between oil yield and seed yield (not presented). These findings were coordinated with the findings of other scholars (Fanaee et al., 2014). In our study, the high protein yield in commercial cultivars was due to higher seed yield, which was effective in increasing protein yield. Furthermore, 
there was a significant correlation between protein yield and seed yield $\left(0.99^{* *}\right)$ (not presented) so increasing protein yield of these cultivars is interpreted. Reduction of protein function was probably due to reducing seed yield under water stress. The results of other researchers were consistent with the findings of this research (Gholinezhad et al., 2009). Our results showed that with increseing water stress, protein percentage enhanced. Increasing protein percentage is due to adaptation to water stress under water deficit. Along with the results of this study, other researchers reported similar results (Mensah et al., 2006). Also protein percentage was enhanced in mycorrhizal plants compared to the nonmycorrhizal plants. The results of this research were parallel with the findings of Timajchi et al. (2010) on the effect of mycorrhizal symbiosis in maize (Zea mays L.) tolerance. In our work, biological yield diminished with increasing water stress. In both application of $F$. mosseae and $R$. intraradices, biological yield increased. The reason for the increase in biological yield under optimum irrigation conditions is probably greater spread and better duration of the leaf surface, resulting in a sufficient physiological source to use as much light as possible and to produce dry matter. These results were consistent with the results of Gholinezhad et al. (2009). Under normal irrigation biological yield enhanced by single AMF and PSB inoculation that is similar to dual colonization (Rahimzadeh and Pirzad, 2017). In our study, by increasing the intensity of water deficit, RWC decreased significantly. Inoculation with AMF increased traits of RWC significantly. The highest relative water content was obtained from "Darab 2". RWC notably was superier in irrigation treatment than water stress. Based on the results, it was exibited that cultivars with the highest yield had the most RWC. Similar to our results, Mensah et al. (2006) stated that with diminishing irrigation, RWC in sesame declined from 79.8 to $66.5 \%$. The rate of RWC in plants with high tolerance versus water stress is more than others. In other words, plants that have preferable yields under water deficit stress should have great RWC.

\section{CONCLUSIONS}

Based on this study for improving the quantitative and qualitative traits of commercial cultivars of sesame, application of $F$. mosseae and $R$. intraradices are suggested. Additionally, the growth extent of $F$. mosseae and $R$. intraradices positively associated with the rate of percentage of root colonization. Mycorrhizal symbiosis clearly led to increase the quantitative and qualitative yield compared to the nonmycorrhizal plants under all the examined irrigation treatments. With enhancing intensity of water deficit, seed yield, number of capsule per plant, number seed per capsule and biological yield decreased significantly. Application of $F$. mosseae, R. intraradices compared to non-inoculated (control) led to raise quantitative and qualitative yield. "Darab 2" and "Darab 14 " accordingly to quantitative and qualitative yield had superiority compared to other commercial cultivars. Therefore, we have proved that the application of the $F$. mosseae, $R$. intraradices can reduce water stress damage by increasing percentage of root colonization that holds water for a long time. For improvement quantitative and qualitative traits of sesame, usage of mycorrhizal fungi, particularly $F$. mosseae can be useful.

\section{ACKNOWLEDGMENTS}

The authors appreciate financial supports provided by Iran National Science Foundation (INSF) (Project no. 93014474).

\section{LITERATURE CITED}

Aslani, Z., A. Hassani, M. Rasooli Sadaghiyani, F. Sefidkon and M. Barin. 2011. Effect of two fungi species of arbuscular mycorrhizal (Glomus mosseae and Glomus intraradices) on growth, chlorophyll contents and $\mathrm{P}$ concentration in Basil (Ocimum basilicum L.) under drought stress conditions. Iranian Journal of Medicinal and Aromatic Plants 27: 471486

Association Official Analytical Chemists. 1990. Official Method of Analysis. Washington, DC, USA.

Bahrami, H., J. Razmjoo and A. Ostadi Jafari. 2012. Effect of drought stress on germination and seedling growth of sesame cultivars (Sesamum indicum L.). Int. J. Agr. Sci. 2: 423-428.

Chamberlain, A.R. 1952. Measuring water in small channels with WSC flume. Agric. Exp. Stn. Circ. 200. State College of Washington, Pullman.

Cho, K., H. Toler, J. Lee, B. Ownely, J.C. Stutz, J.L. Moore and R.M. Auge. 2006. Mycorrhizal symbiosis and response of sorghum plants to combined drought and salinity stresses. J. Plant Physiol. 163: 517-528.

Davoodi Fard, M., H. Paknezhad, F. Fazeli and P. Farahani Pad. 2011. Effect of plant growth promoting rhizobacteria and foliar application of amino acids and silicic acid on antioxidant enzyme activity of wheat under drought stress. Iranian Journal of Agronomy and Plant Breeding 6: 11-36.

Dhopte, A.M. and L.M. Manuel. 2002. Principles and techniques for plant scientists. $1^{\text {st }}$ Edn., Updesh Purohit for Agribios (India), Odhpur, IBSN: 81-7754-116-1, pp: 373.

Diouf, M., S. Boureima and T. Diop, et al. 2010. Gamma raysinduced mutant spectrum and frequency in sesame. Turk. J. Field Crops. 15(1): 99-105.

Fagria, N.K. 1995. Increasing yield of crops. Translated by: Hashemi Dezfoli, S.A. and A. Kocheki. Mashhad University Press. 287 pages.

Fanaee, H., M. Naroee Rad and M. Mohammad Ghasemi. 2014. Evaluation of seed yield, yield components and tolerance to drought stress of spring canola genotypes. Seed and Plant. 30: 269-287.

FAO. 2016. Yearbook production. FAO Pub. Rome, Itlay.

Ganji Arjenaki, F., R. Jabbari and A. Morshedi. 2012. Evaluation of drought stress on relative water content, chlorophyll content and mineral elements of wheat (Triticum aestivum L.) varieties. Int. J. Agric. Crop Sci. 4: 726-729.

Gholinezhad, E., A. Ayneband, A. Hassanzadeh Ghorttapeh, Gh. Noormohammadi and I. Bernousi. 2010. Effect of irrigation regimen on water and nitrogen use efficiency of Var. Iroflor sunflower in different amounts of nitrogen and plant density in Urmia. J. Agric. Sci. 20: 24-75.

Gholinezhad, E., A. Ayneband, A. Hassanzadeh Ghorttapeh, I. Bernousi and H. Rezaei. 2009. Evaluation of effect of drought stress with nitrogen levels and plant density on seed yield and yield components and harvest index of Var. Iroflor sunflower in Urmia. J. Plant Prod. Res. 16: 1-28.

Habibzadeh, Y., A. Pirzad, M.R. Zardashtai, J. Jalilian and O. Eini. 2012. Effects of Arbuscular Mycorrhizal Fungi on seed 
and protein yield under water-deficit stress in Mung Bean. Agron. J. 105: 79-84.

Haghighatnia, H., H. Nadian, F. Rejali and F. Tavakoli. 2012. Effect of two species of arbuscular-mycorrhizal fungi on vegetative growth and phosphorous uptake of Mexican lime rootstock (Citrus aurantifolia) under drought stress conditions. Seed and Plant. 2: 403-417.

Heidari, M., M. Galavi and M. Hassani. 2011. Effect of sulfur and iron fertilizers on yield, yield components and nutrient uptake in sesame (Sesamum indicum L.) under water stress. Afr. J. Biotechnol. 10: 816-8822.

Jamshidi, A., A. Ghalavand, M.J. Zare and F.A.R. Jamshidi. 2009. Effect of arbuscular mycorrhiza on yield, yield components and properties of sunflower in drought conditions (Helianthus annuus L.). Iranian Journal of Crop Science. 11: 136-150.

Ladjal, M., R. Huc and M. Ducrey. 2005. Drought effects on hydraulic conductivity and xylem vulnerability to embolism in diverse species and provenances of Mediterranean cedars. Tree Physiol. 25: 1109-1117.

Mehrabi, Z. and P. Ehsanzadeh. 2011. A study on physiological attributes and seed yield of sesame (Sesamum indicum L.) cultivars under different soil moisture regimes. J. Crops Improv. 13: 75-88.

Mensah, J.K., B.O. Obadoni, P. Eruotor and F. Onome-Trieguna. 2006. Simulated flooding and drought effects on germination, growth and yield parameters of sesame. Afr. J. Biotechnol. 13: 1249-1253.

Mugendi Njerua, E., G. Boccia, L. Aviob, C. Sbranab, A. Turrinic, M. Giovannettic and P. Bàrberiaa. 2017. Functional identity has a stronger effect than diversity on mycorrhizalsymbiosis and productivity of field grown organic tomato. Eur. J. Agron. 86: 1-11.

Phumichai, C., W. Matthayatthaworn and N. Chuenpom, et al. 2017. Identification of a scar marker linked to a shattering resistance trait in sesame. Turk. J. Field Crops. 22(2): 258265 .
Raei, Y., J. Shariati and W. Weisany. 2015. Effect of biological fertilizers on seed oil, yield and yield components of safflower (Carthamus tinctorius L.) at different irrigation levels. J. Agric. Sci. Suit. Prod. 25: 65-84.

Rahimzadeh, S. and A. Pirzad. 2017. Arbuscular mycorrhizal fungi and Pseudomonas in reduce drought stress damage in flax (Linum usitatissimum L.): a field study. Mycorrhiza. 27: 537-552.

Rejali, F., A. Alizadeh, M. Malakoti and S. Rastin. 2007. Effect of the association of arbuscular mycorrhizal symbiosis on growth, yield and absorption of mineral elements in wheat under drought stress. J. Soil Water Sci. 21: 241-259.

Rezvani Moghaddam, P., M.B. Amiri and M. Seyyedi. 2014. Effect of organic and bio-fertilizers application on yield, oil content and fatty acids composition of sesame (Sesame indicum L.). Iranian Journal of Crop Sciences. 16: 209-221.

Sainz, M.J., M.T. Taboada-Castro and A. Vilarino. 1998. Growth, mineral and mycorrhizal colonization of red clover and cucumber plants grown in a soil amended with composted urban wastes. Plant Soil. 205: 85-92.

Sogut, T. 2009. Effect of main and second cropping on seed yield, oil and protein content of sesame genotypes. Turk. J. Field Crops. 14(2): 64-71.

Timajchi, M., A. Kashani, M.R. Ardakani, F. Rejali, M. Abbasian and M. Seyfi. 2010. Comparison of the nano, biological and chemical fungicides effect on the protein seed quantity and leaf nitrogen of corn (CV. Sc-704) with mycorrhiza symbiosis. $5^{\text {th }}$ National Conference New Ideas in Agriculture, 17-18 Feb. 2010. Azad University of Khorasghan, Isfahan, Iran.

Xue-Guang, S. and T. Ming. 2012. Comparison of four routinely used methods for assessing root colonization by arbuscular mycorrhizal fungi. Botany. 90: 1073-1083.

Yol, E., S. Furat and B. Uzun. 2013. Genetic control of purple plant color in sesame. Turk. J. Field Crops. 18(2): 229-232.

Yol, E., C. Toker and B. Uzun. 2017. Inheritance of long and dense capsule characteristics in sesame. Turk. J. Field Crops. 22(1): 8-13. 